\title{
Mechanism of Cell Death
}

National Cancer Institute

\section{Source}

National Cancer Institute. Mechanism of Cell Death. NCI Thesaurus. Code C51035.

A biological process that results in permanent cessation of all vital functions of a cell. 